\title{
Kelompok Suportif Hipertensi di Desa Sambimulyo dan Desa Seneporejo Kabupaten Banyuwangi
}

\author{
Mad Zaini ${ }^{\# 1}$, Ginanjar Sasmita Adi ${ }^{\# 2}$ \\ \#1,2 Program Studi Ilmu Keperawatan, Fakultas Ilmu Kesehatan, Universitas Muhaamdiyah Jember Jl. Karimata No. 45 \\ Jember
}

\begin{abstract}
Hipertensi pada seorang menjadi pemicu terjadinya masalah dalam kehidupan, tidak hanya masalah fisik, tetapi juga masalah dalam kehidupan sehari-hari. Perubahan fungsi tubuh akibat hipertensi, ancaman terhadap integritas diri, pengobatan serta perubahan peran dalam kehidupan sehari-hari diyakini menjadi penyebab munculnya masalah sosial dan ekonomi. Untuk mengatasi masalah tersebut, maka perlu pelayanan yang komprehensif. Pelayanan dapat dilakukan dalam bentuk menggerakkan dan memberdayakan potensi di masyarakat, terutama warga masyarakat, tokoh masyarakat serta profesi di bidang kesehatan. Sebagai wujud partisipasi profesi bidang kesehatan, maka dilaksanakan program kemitraan masyarakat "kelompok suportif hipertensi" yang berlokasi di Desa Sambimulyo dan Desa Seneporejo Kabupaten Banyuwangi. Tujuan kegiatan kemitraan ini adalah mengatasi masalah utama yang dihadapi penderita hipertensi yaitu kurangnya pengetahuan tentang perawatan hipertensi serta kurangnya kemampuan yang adaptif pada penderita dan keluarga. Luaran yang didapatkan adalah terbentuk kelompok suportif hipertensi dan tersusun modul suportif hipertensi. Selain itu, kegiatan kemitraan ini berjalanan dengan baik dan mendapatkan dukungan dari pemerintah desa dan masyarakat yang ada di Desa Sambimulyo dan Desa Seneporejo,
\end{abstract}

Keywords: Kelompok Suportif, Hipertensi

\section{Pendahuluan}

Masalah kesehatan fisik dan masalah kesehatan jiwa sering kali berjalan beriringan. Pada saat individu pengalami masalah kesehatan fisik, pada saat yang sama, memungkinkan individu tersebut juga mengalami masalah kesehatan jiwa tetapi sering kali tidak mendapatkan pelayanan asuhan keperawatan atau asuhan medis dengan baik. Asuhan keperawatan di era globalisasi ini harus didasarkan pada satu konsep yang meliputi aspek fisik, psikologis, sosiokultural dan spiritual (Kretchy et al 2014). Aspek-aspek tersebut merupakan satu kesatuan yang utuh, apabila satu aspek terganggu akan mempengaruhi aspek yang lain.

Masalah kesehatan fisik masih menjadi ancaman kesehatan masyarakat terutama pada penyakit tidak menular (PTM) misalnya hipertensi, stroke, penyakit jantung dan diabetes mellitus. Secara umum, penyakit tidak menular (PTM) yang menjadi penyebab mortilitas nomor satu setiap tahunnya adalah penyakit kardiovaskuler (WHO, 2013). Hipertensi merupakan salah satu faktor risiko terbesar penyabab mortilitas dan mordibitas pada penyakit kardiovaskular (Kretchy et al 2014). Kondisi tersebut menunjukkan bahwa masih banyak kejadian hipertensi di masyarakat yang belum terdiagnosa dan mendapatkan pelayanan kesehatan secara baik. Berdasarkan uraian diatas, klien dengan hipertensi akan mengalami perubahanperubahan baik secara fisik maupun sosial. Perubahanperubahan yang dialami klien hipertensi seperti perubahan gaya hidup, diet, kegiatan pengobatan yang rutin menjadi stresor terhadap munculnya masalah kesehatan jiwa seperti kecemasan dan depresi.

Hipertensi dan proses adaptasi terhadap perubahan tubuh akibat hipertensi masih menjadi masalah kesehatan, tidak hanya masalah kesehatan fisik tetapi juga masalah psikologis dan sosial. Masalah psikologis dan sosial tidak hanya dialami oleh individu sebagai klien tetapi juga oleh keluarga yang merawatnya (Strom, J.L \& Egede, L.E. 2013). Angka kejadian hipertensi di Indonesia sebesar $26,5 \%$ pada tahun 2013, dari angka tersebut yang terdiagnosa oleh tenaga kesehatan atau dengan riwayat minum obat hanya 9,5\% (Kemenkes RI, 2013). Hasil riset kesehatan dasar tahun 2013 terkait masalah kesehatan jiwa yang disebabkan oleh masalah fisik, psikologis atau sosial menyatakan bahwa prevalensi terjadinya masalah kesehatan jiwa ringan atau gangguan mental emosional adalah sebesar $6,0 \%$ dari jumlah penduduk Indonesia. Data tersebut berarti setiap 100 orang penduduk terdapat 6 orang yang megalami gangguan mental emosional yang sebagian besar disebabkan oleh penyakit fisik yang bersifat kronis. Hasil penelitian yang dilakukan pada individu usia 15 tahun lebih mengalami satu diantara penyakit kronis yaitu penyakit kardiovaskuler, DM, Stoke, TBC, Ca, dan penyakit liver terdapat tanda dan gejala yang mengarah pada gangguan mental emosional (Widakdo \& Besral, 2013). Kondisi seperti ini menunjukkan bahwa masalah kesehatan jiwa masih banyak terjadi namun berbagai kebijakan yang ditetapkan terkait pelayanan kesehatan jiwa di masyarakat masih berfokus pada masalah masalah kesehatan fisik (Dirjen Med \& WHO, 2012). Masalah psikososial di 
masyarakat sering kali tidak terdeteksi karena pelayanan kesehatan yang diberikan lebih mengutamakan keluhan fisik (Videbeck, 2010).

Peningkatan masalah psikologis dan sosial pada penderita hipertensi dapat ditekan dengan menyediakan sarana pelayanan kesehatan yang berorientasi pada kemandirian masyarakat. Kemandirian masyarakat dalam mengatasi masalah kesehatan akan berkembang ketika anggota masyarakat terutama kelompok-kelompok beresiko mempunyai pengetahuan dan pemahaman yang benar tentang masalah kesehatan yang dialami serta adanya sistem pendukung baik internal maupun eksternal ikut serta dalam mendukung meningkatkan derajat kesehatan anggota masyarakat (Dirjen Med \& WHO, 2012).

Dampak dari masalah psikologis dan sosial akibat hipertensi akan mempengaruhi pola kehidupan pada individu dan keluarga. dampak yang berlangsung lama akan menyebabkan konflik pada individu maupun pada keluarga. tindakan manajemen stress pada individu dan keluarga dapat menyelesaikan masalah-masalah yang berhubungan dengan kondisi fisik, psikologis dan sosial. Adanya kelompok suportif pada individu hipertensi atau keluarga sebagai care giver bagi penderita hipertensi sangat diperlukan untuk membantu menyelesaikan masalah. Kelompok suportif merupakan alternatif pilihan yang ditujukan untuk meningkatkan kemampuan individu dan keluarga sebagai support system dalam merawat anggota keluarganya yang sakit. Kelompok suportif juga membantu anggota kelompok untuk saling bertukar informasi dan masalah tertentu supaya meningkatkan mekanisme koping.

Prevalensi kejadian hipertensi di Kabupaten Banyuwangi menunjukkan hasil yang terus meningkat dari tahun ke tahun. Kondisi ini juga dipengaruhi oleh rendahnya kesadaran masyarakat untuk berperilaku sehat (Dinas Kabupaten Banyuwangi, 2016). Mengacu pada Prevalensi masalah-masalah kesehatan seperti hipertensi di Kabupaten Banyuwangi yang terus meningkat, maka Program Kemitraan Masyarakat "Kelompok Suportif Hipertensi" menitik beratkan pada upaya preventif dan rehabilitatif masalah kesehatan fisik dan psikososial untuk memberikan resolusi permasalahan dengan segera, memberikan motivasi dan perubahan perilaku individu dan keluarga denga hipertensi.

\section{TARGET DAN LUARAN}

Target dari kegiatan pengabdian ini adalah peningkatan pengetahuan masyarakat di wilayah mitra melalui kegiatan penyuluhan kesehatan. Dalam penyuluhan kesehatan ini, target peserta pada setiap mitra adalah 20 orang. Target ini tercapai dengan beberapa upaya kegiatan tambahan seperti kegiatan pemeriksaan kesehatan secara gratis kepada masyarakat.

Luaran dari kegiatan ini adalah terbentuknya kelompok suportif hipertensi di kedua wilayah mitra melalui 4 sesi. Luaran lain yang dihasilkan adalah tersusun modul yang dapat digunakan sebagai panduan kegiatan kelompok suportif hipertensi. Luaran lainnya adalah artikel ilmiah yang akan dipublikasikan pada jurnal pengabdian masyarakat.

\section{MATODE PELAKSANAAN}

Tahapan dalam melaksanakan kegiatan pengabdian masyarakat Kelompok Suportif Hipertensi adalah :

\section{A. Sosialisasi}

Kegiatan sosialisasi dilakukan pada individu dan keluarga di wilayah mitra melalui kegiatan pendidikan kesehatan dan pemeriksaan kesehatan secara gratis.

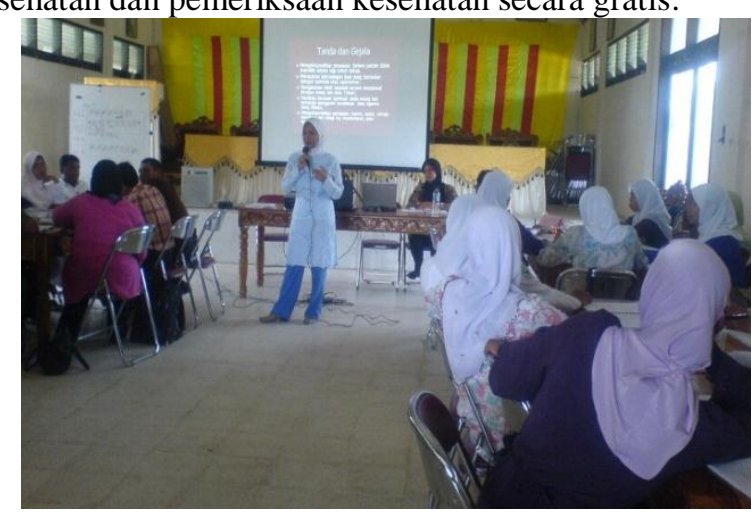

Gambar 1. Sosialisasi kegiatan

\section{B. Kegiatan persiapan pembentukan kelompok}

Tahapan ini dilakukan melalui kegiatan koordinasi dengan tokoh masayarakat, tokoh agama dan Petugas Kesehatan di Desa Kedungrejo dan Desa Seneporejo Kabupaten Banyuwangi.

\section{Pelaksanaan kegiatan pengabdian}

Tahapan dalam pelaksanaan kegiatan pengabdian ini meliputi penentuan setting dan ukuran kelompok, lamanya sesi pertemuan, memutuskan sifat kelompok, memformulasikan aturan kelompok. Selanjutnya pelaksanaan kegiatan suportif hipertensi yang terdiri dari 4 sesi.

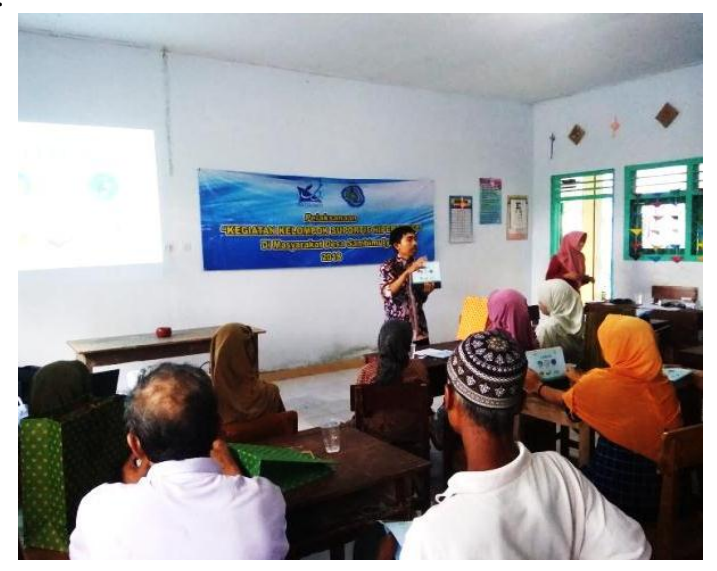

Gambar 2. Kegiatan Pembentukan Kelompok Suportif Hipertensi 


\section{KELAYAKAN PERGURUAN TINGGI}

Dalam kurun waktu 5 tahun terakhir, LPPM Universitas Muhammadiyah Jember (UM Jember) mempunyai kinerja yang baik. LPPM UM Jember telah banyak mendapatkan pendanaan dari Ristek Dikti. Tim pelaksana dalam kegiatan pengabdian ini terdiri dari 2 orang dosen. Dalam kegiatan ini dibutuhkan bidang kepakaran keperawatan medical bedah dan keperawatan kesehatan jiwa masyarakat. Selain dosen, kegiatan ini juga melibatkan mahasiswa dengan harapan sebagai bentuk penerapan materi yang didapatkan selama kuliah.

\section{HASIL DAN LUARAN YANG DICAPAI}

Hasil kegiatan Program kemitraan Masyarakat (PKM) di 2 mitra yang telah dilakukan adalah:

- Melakukan pendidikan kesehatan disertai dengan pemeriksaan kesehatan yang terdiri dari pemeriksaan tekanan darah, gula darah dan kolesterol

- Melakukan sosialisasi tentang program kemitraan masyarakat suportif hipertensi

- Melakukan kegiatan suportif hipertensi

Dari ketiga kegiatan tersebut dapat diuraikan sebagai berikut:

1) Pendidikan kesehatan disertai dengan pemeriksaan kesehatan: Kegiatan pendidikan kesehatan pada mitra I dan mitra II dilaksanakan pada bulan April 2018. Materi yang disampaikan terdiri atas pengertian hipertensi, tanda dan gejala, pencegahan serta perawatannya. Kegiatan pendidikan kesehatan dilanjutkan dengan pemeriksaan kesehatan pada peserta yang menderita atau berisiko hipertensi. Hasil dari pelaksanaan pendidikan kesehatan adalah peserta sangat antusias dengan materi yang diberikan, adanya leaflet sangat membantu peserta untuk memahami materi yang disampaikan. Evaluasi awal dari pemberian pendidikan kesehatan terkait dengan pengetahuan masyarakat tentang hipertensi dan cara merawatnya masih kurang, hal ini dibuktikan dengan masih banyak peserta yang belum tanda-tanda hipertensi serta pola makan yang benar bagi penderita hipertensi. Hasil pemeriksaan kesehatan pada masyarakat di kedua mitra menunjukkan bahwa $80 \%$ peserta yang hadir mempunyai tekanan darah >140/90 mmHg, gula darah sewaktu >100 $\mathrm{mg} / \mathrm{dl}$ dan kolesterol $>150 \mathrm{mg} / \mathrm{dl}$.

2) Sosialisasi program kemitraan masyarakat suportif hipertensi: Pelaksanaan sosialisasi program kemitraan masyarakat dilaksanakan sebanyak 2 kali pada masingmasing mitra. Sosialisasi pertama pada mitra I dilaksanakan pada tanggal 23 April 2018, sedangkan pada mitra II dilaskanakan pada tanggal 25 April 2018. Sosialisasi kedua pada mitra I dilaksanakan pada tanggal 30 April 2018, sedangkan pada mitra II dilaksanakan pada tanggal 02 Mei 2018. Peserta yang ikut dalam kegiatan sosialisasi didasarkan atas hasil pemeriksaan kesehatan berupa tekanan darah, gula darah dan kolesterol yang nilainya diatas normal, yaitu sejumlah 20 orang pada mitra I dan 20 orang pada mitra II.

Hasil dari kegiatan sosialisasi program kemitraan masyarakat diantaranya adalah kegiatan sosialisasi berjalan dengan baik, adanya kesadaran dan kesepatan diantara peserta untuk saling membantu diantara sesama anggota masyarakat dalam menjaga kesehatan, kesepakatan untuk melanjutkan kegiatan dalam bentuk kelompok suportif yang terdiri dari minimal 15 orang, kegiatan kelompok suportif dilakukan minimal 3-4 minggu sekali, lama kegiatan maksimal 60 menit dan ketentuan lainnya seperti setiap anggota kelompok harus ikut aktif dalam kegiatan suportif ini.

3) Melakukan kegiatan suportif hipertensi: Pelaksanaan kegiatan suportif hipertensi dilaksanakan selama 2 kali pertemuan, guna memberikan pembekalan kepada masyarakat dalam merawat hipertensi yang dialami. Peserta yang ikut dalam kegiatan suportif pada mitra I dan mitra II masing-masing sebanyak 20 orang. Kegiatan suportif yang dilakukan diantaranya mengidentifikasi kemampuan individu dan sumber pendukung dari dalam dan luar individu (keluarga), latihan menggunakan sumber pendukung dari dalam dan luar individu. Hasilnya kegiatan suportif berjalan dengan lancar, para peserta berperan aktif selama kegiatan dibuktikan dengan beberapa pertanyaan diajukan oleh anggota kelompok. kegiatan dibuktikan dengan beberapa pertanyaan diajukan oleh anggota kelompok.

\section{KESIMPULAN DAN SARAN}

\section{A. Kesimpulan}

Program kemitraan masyarakat ini banyak memberikan manfaat bagi masyarakat, bentuk nyata dari kegiatan ini adalah peningkatan pengetahuan dan pemahaman tentang tekanan darah tinggi. Setelah terjadi peningkatakan pengetahuan dan pemahaman diharapkan diikuti kesadaran pentingnya perilaku "Cerdik" pada penderita hipertensi.

\section{B. Saran}

Diharapkan kegiatan kelompok seperti kelompok hipertensi ini dilakukan pada kelompok-kelompok lain terutama kelompok masyarakat yang beresiko tinggi terjadi masalah kesehatan, serta perlunya dukungan dari semua pihak yang ada di masyarakat. 
Jurnal Pengabdian Masyarakat J-DINAMIKA, Vol. 3, No. 2, Desember 2018,

P-ISSN: 2503-1031, E-ISSN: 2503-1112

\section{DAFTAR PUSTAKA}

[1] Dirjen Med \& WHO (2012). Word Health Organization Psychiatric Prevalence in General Health Care. Jakarta

[2] Kemenkess RI. (2013). Peraturan Menteri Kesehatan RI No. 75 tahun 2014 tentang Pusat Kesehatan Masyarakat (Puskesmas). Jakarta.

[3] Perry, A.G. Potter, P.A, (2010). Buku Ajar Fundamental Keperawatan : Konsep, Proses, dan Praktik. Edisi 7. Volume 2. Alih Bahasa : Renata Komalasari,dkk. Jakarta: EGC.

[4] Strom, J.L \& Egede, L.E. (2013) The Impact of Social Support on Outcomes in Adult Patients with Type 2 Diabetes: A Systematic Review. http://www.ncbi.nlm.nih.gov/pmc/articles/PMC3490012/

[5] Stuart, G.W. (2013). Principles and practice of psychiatric nursing. (9th ed). St Louis: Mosby Year Book

[6] Videbeck, S.L. (2010). Psychiatric Mental Health Nursing. Philadelphia: Lippincott Williams \& Wilkins. 